\title{
Pelatihan Diversifikasi Produk Olahan Jagung Manis Di Kelurahan Kalampangan Kota Palangka Raya
}

\author{
Susi Kresnatita dan Oesin Oemar \\ Jurusan Budidaya Pertanian, Fakultas Pertanian Universitas Palangka Raya \\ Email : susikresnatita@yahoo.co.id
}

\begin{abstract}
Abstrak
Kegiatan pelatihan diversifikasi produk olahan jagung manis telah dilaksanakan di Kelurahan Kalampangan Kota Palangka Raya. Keberhasilan pertanian lahan gambut Desa Kalampangan, salah satunya ditunjang oleh sektor hortikultura. Umumnya pemenuhan kebutuhan sayuran sekitar Kota Palangka Raya dipasok dari Desa Kalampangan. Desa Kalampangan merupakan sentral produksi jagung manis di wilayah Kota Palangka Raya. Luas areal penanaman jagung manis menempati urutan teratas yaitu seluas 205 ha dengan produksi sebesar 215 ton/ha. Produksi ini sesuai dengan deskripsi varietas jagung manis dataran rendah Kegiatan pengabdian ini telah dilaksanakan pada bulan September sampai Oktober 2019 dengan kelompok sasaran ibu - ibu petani Desa Kalamapnagan. Metode kegiatan meliputi : 1) Sosialisasi dan Penyuluhan, 2) Pelatihan dan demontrasi, 3) Pembinaan/ pendampingan, 4) Monitoring. Tujuan dari kegiatan pelatihan diversifikasi produk olahan jagung manis. berupa puding dan kue talam diharapkan menjadi rintisan wirausaha bagi ibu - ibu petani Desa Kalampangan, adapun untuk pengolahan produk makanan ini hanya perlu teknologi yang sederhana. Sedangkan kontribusi yang diberikan kepada ibu - ibu petani mitra adalah dengan pelatihan pembuatan dua produk makanan yang terbuat dari jagung manis (puding dan kue talam jagung manis), diharapkan menjadi rintisan wirausaha baru skala home industri sehingga dapat menambah pendapatan income keluarga sekaligus untuk konsumsi sendiri guna memenuhi gizi keluarga. Dari kegiatan pelatihan ini diharapkan dapat menjaga kestabilan harga jagung manis di tingkat petani serta ada nilai tambah dari hasil produk olahan jagung manis. Adapun kekurangan yang perlu diperbaiki guna menunjang keberlanjutan rintisan usaha produk olahan puding dan kue talam jagung manis adalah perlu perbaikan pada wadah/tempat kemasan produk. Produk hasil olahan yang dikemas dengan wadah/ tempat yang cantik dan menarik serta tertutup sangat mempengaruhi kualitas hasil produk yaitu meningkatkan daya tarik bagi pembeli dan lebih higienis serta meningkatkan harga jual. Dari hasil kegiatan pengabdian ini disarankan perlu dicari inovasi teknologi guna peningkatan waktu saji yang lebih tahan lama (produk tidak mudah basi) karena produk olahan puding dan kue talam hanya bertahan setengah hari saja.
\end{abstract}

Kata kunci : Jagung manis, puding, kue talam, Kalampangan

\section{Pendahuluan}

Kalampangan terletak $18 \mathrm{~km}$ sebelah utara Kota Palangka Raya, Provinsi Kalimantan Tengah, merupakan Desa eks trans yang mulai dibuka pada tahun 1979. Kelurahan ini terdiri dari 3.066 jiwa menempati areal seluas \pm 5000 ha. Desa Kalampangan dibangun diatas tanah gambut dengan kedalaman \pm 4 meter, merupakan profil pedesaan yang berhasil di lahan gambut. Keberhasilan pertanian lahan gambut Desa Kalampangan, salah satunya ditunjang oleh sektor hortikultura. Usahatani dilakukan pada lahan seluas \pm 0,25 ha, dengan menggunakan pola tanam secara rotasi dengan berbagai komoditas sayur-sayuran. Umumnya pemenuhan kebutuhan sayuran sekitar Kota Palangka Raya dipasok dari Desa Kalampangan.

Usahatani di Kalampangan tidak mengenal musim, karena pada umumnya tanaman sayuran yang dibudidayakan merupakan sayuran dataran rendah yang dapat tumbuh dan berproduksi setap saat tanpa mengenal musim seperti jagung manis, sawi, kacang panjang, kangkung cabut, bayam, dan lain - lain.

Direktorat Jenderal Pemberdayaan Masyarakat dan Desa, 2015 menyatakan bahwa luas areal penanaman jagung manis menempati urutan teratas/pertama yaitu seluas 205 ha dengan produksi sebesar 215 ton/ha. Produksi ini sesuai dengan deskripsi varietas jagung manis dataran rendah. Desa 
Kalampangan merupakan sentral produksi jagung manis di wilayah Kota Palangka Raya. Jagung manis merupakan salah satu jenis jagung yang banyak dikonsumsi masyarakat. Rasanya yang manis disebabkan oleh tingginya kandungan gula di dalam bijinya. Keberadaan gula yang cukup tinggi dalam jagung manis dapat dimanfaatkan sebagai pemanis alami serta mengandung pigmen karotenoid antara $6,4-11,3 \mu \mathrm{g} / \mathrm{g}$, sekitar $22 \%$ diantaranya adalah $\beta$-karoten dan $51 \%$ xantofil. Diketahui bahwa $\beta$-karoten merupakan senyawa yang memiliki aktivitas antioksidan dan provitamin $\mathrm{A}$.

\section{Permasalahan Mitra}

Sebagian besar masyarakat petani Desa Kalampangan menanam tanaman jagung manis sehingga saat panen melimpah (surplus) harga jualnya menjadi sangat murah (harga per kg hanya sekitar Rp. 5.000 - 6.000 di tingkat petani) bahkan sebagian produk hasil jagung manis yang kualitasnya rendah (kecil - kecil dan isi tongkol tidak penuh bijinya tidak laku terjual. Kondisi ini menyebabkan petani tidak mendapatkan keuntungan karena biaya usaha tani relatif cukup tinggi.

Berdasarkan permasalahan tersebut sehingga perlu diadakan pelatihan pengolahan diversifikasi produk olahan berbahan dasar jagung manis. Dengan adanya kegiatan pelatihan ini diharapkan harga jual jagung manis tetap bisa dipertahankan. Pemanfaatkan jagung manis menjadi produk olahan berupa puding dan kue talam diharapkan menjadi rintisan wirausaha baru bagi ibu - ibu petani desa Kalampangan. Kegiatan pelatihan ini diharapkan dapat menambah penghasilan dan pendapatan bagi ibu - ibu petani. Letak Desa Kalampangan yang cukup strategis, jalur utama jalan provinsi yang menghubungkan Kalimantan Tengah dan Kalimantan Selatan, sehingga sangat menguntungkan apabila hasil produk olahan tersebut dipasarkan pada jalur utama trans Kalimantan yang selalu ramai dengan lalu lintas transpotasi darat.

Tujuan dari pelatihan ini adalah :

1. Untuk memberikan solusi pada mitra bagaimana memanfaatkan panen jagung manis yang cukup melimpah di areal Desa Kalampangan untuk diolah menjadi produk pangan yang bergizi dan bernilai jual dengan teknologi yang sederhana.

2. Meningkatkan pengetahuan dan ketrampilan serta peluang wirausaha daru skala home industry bagi ibu - ibu petani dalam pengolahan diversifikasi produk olahan jagung manis berupa puding dan kue talam, guna menambah pendapatan keluarga.

\section{Metode Pelaksanaan}

\section{Tempat dan Waktu Kegiatan}

Kegiatan Pengabdian Kepada Masyarakat telah dilaksanakan di rumah kediaman Ibu Ketua Kelompok Tani yaitu ibu Rukayah Jl. Doho No.03 Kelurahan Kalampangan Kecamatan Sabangau, Kota Palangka Raya, dengan diikuti oleh sekitar 20 orang ibu-ibu petani.

\section{Metode}

Metode yang digunakan selama kegiatan meliputi : 1) Sosialisasi dan penyuluhan interaktif 2) Pelatihan dan demontrasi cara pengolahan jagung manis menjadi puding dan kue talam 3) Pembinaan/pendampingan selama kegiatan berlangsung 4) Monitoring setelah kegiatan, baik melalui tinjauan lapang maupun telp. untuk mengevaluasi tingkat ketrampilan yang diperoleh selama kegiatan serta memotivasi khalayak sasaran.

Sebelum kegiatan tim melakukan: 1) Survei lokasi dan diskusi tentang teknis pelaksanaan kegiatan dengan ibu ketua kelompok tani 2) Uji coba pembuatan puding dan kue talam 
berbahan dasar jagung manis dengan tim 3) Pemantapan serta pembagian tugas dengan tim saat kegiatan berlangsung serta koordinasi dengan mahasiswa pendamping yang terlibat selama kegiatan.

\section{Pelaksanaan kegiatan}

Kegiatan dilaksanakan dalam 2 bentuk, yaitu :

a. Penyuluhan interaktif tentang proses pembuatan produk olahan berbahan jagung manis.

b. Pelatihan berupa demonstrasi pembuatan puding dan kue talam.

\section{Demonstrasi}

Demonstrasi pembuatan produk olahan jagung manis meliputi proses pembuatan puding dan kue talam. Pada saat praktek pembuatan puding dan kue talam, juga dilakukan diskusi antara tim pelaksana dengan ibu - ibu petani peserta kegiatan. Diskusi berhubungan dengan kejelasan setiap langkah dari proses pembuatan produk, modifikasi yang dilakukan, modal yang dibutuhkan, dan harga jual produk bagi khalayak sasaran yang ingin mengembangkan usaha pengolahan jagung manis tersebut secara komersial, meskipun masih dalam skala home industry.

\section{Pembuatan Puding Jagung Manis}

\section{Bahan :}

a. Susu kental manis $\pm 20 \mathrm{sdm}$ yang dicairkan $750 \mathrm{ml}$

(apabila menggunakan susu UHT 750 $\mathrm{ml}$ ditambahkan gula $30 \mathrm{gr}$ )

b. Gula Pasir \pm 120 gr

c. Tepung maizena $30 \mathrm{gr}$

d. Agar-agar bubuk warna putih 2 bungkus

e. Jagung manis yang telah disisir \pm 300 gr ( \pm 2 buah tongkol jagung manis)

f. Air $\pm 400 \mathrm{ml}(200 \mathrm{ml}$ untuk memblender jagung manis sisir sampai halus, dan 200ml untuk memasaknya)

\section{Cara membuat :}

1. Didihkan $200 \mathrm{ml}$ air lalu masukan biji jagung manis yang sudah diblender halus, aduk-aduk sampai masak dan mengental (bubur jagung manis).

2. Masukkan gula ke dalam 3/4 bagian susu cair (1/4 sisanya untuk melarutkan agar-agar dan tepung maizena supaya tidak menggumpal) kemudian masak dengan api sedang sambil diaduk terus hingga mendidih, kemudian masukkan bubur jagung manis (point 1) sambil terus diaduk dengan api kecil agar adonan tidak meluber keluar hingga benar-benar mendidih.

3. Setelah mendidih tuang ke dalam loyang dan dinginkan.

\section{Pembuatan Kue Talam Jagung Manis}

\section{Bahan :}

a. Tepung hung kwee 2 bungkus (1 bungkus warna putih dan 1 bungkus warna kuning)

b. Garam $1 / 2 \mathrm{sdt}$

c. Gula pasir $\pm 90 \mathrm{gr}$

d. Tepung beras $2 \mathrm{sdm}$

e. Jagung manis yang telah disisir \pm 300 gr ( \pm 2 buah tongkol jagung manis)

f. Air $\pm 400 \mathrm{ml}(200 \mathrm{ml}$ untuk memblender jagung manis sisir tidak sampai halus/masih terasa butirannya dan $200 \mathrm{ml}$ untuk memasak)

g. Santan $\pm 500 \mathrm{ml}$

h. Susu kental manis putih 5 sendok makan

i. Daun pisang untuk takir dan padan untuk hiasan toping

\section{Cara membuat :}

1. Siapkan terlebih dahulu daun takir yang terbuat dari daun pisang dan irisan kecil daun padan untuk hiasan/ toping.

2. Didihkan $200 \mathrm{ml}$ air lalu masukan jagung manis yang telah diblender kasar, aduk-aduk sampai matang dan mengental, tunggu sampai dingin. 
3. Campur dan masukkan semua bahan (a - h) ke dalam panci, lalu tambahkan santan sambil diaduk hingga tercampur rata, lalu masak dengan api sedang hingga mengental, kemudian masukkan rebusan adonan jagung manis (point 2), sambil terus di aduk dan rebus hingga benar-benar matang (adonan mengental dan meletup-letup) selama \pm 20 menit.

4. Tunggu sampai panasnya agak berkurang. segera masukan dalam takir daun pisang dan beri toping irisan kecil daun pandan, sebagai hiasan/ pemanis.

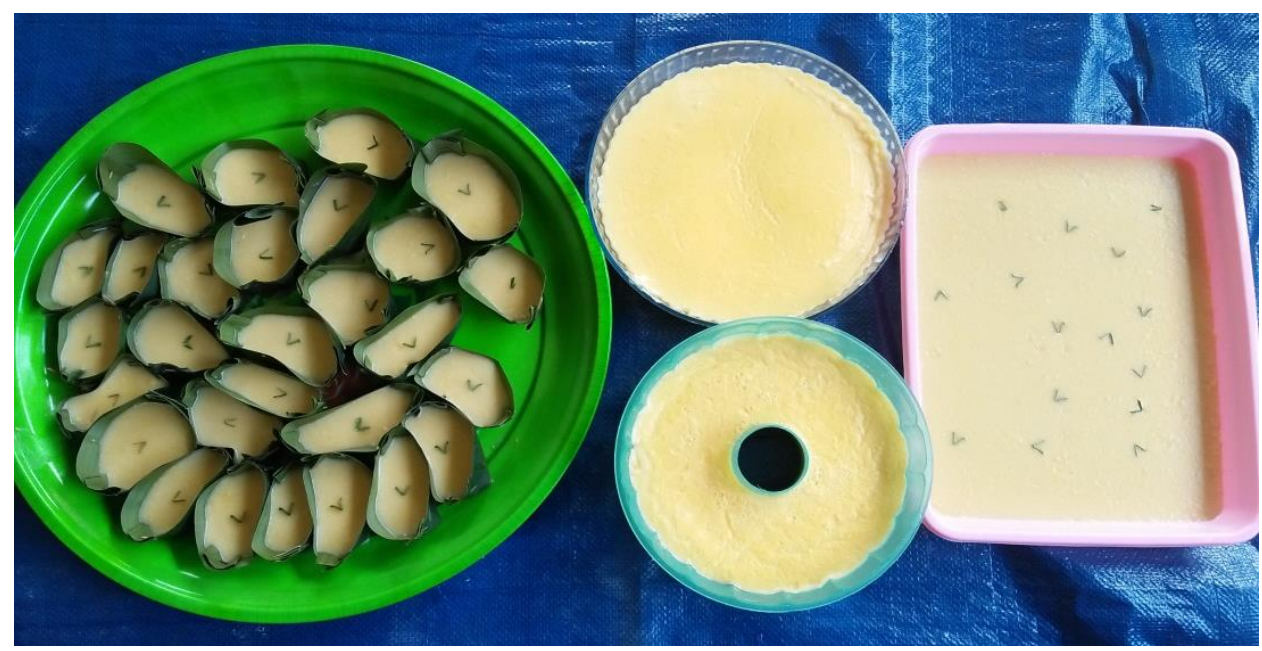

Gambar 1. Hasil Produk Olahan Puding dan Kue Talam Jagung Manis

\section{Hasil Kegiatan}

Pelatihan diversifikasi produk olahan berbahan dasar jagung manis. berupa puding dan kue talam diharapkan menjadi rintisan wirausaha baru bagi ibu ibu petani Desa Kalampangan. Kegiatan pelatihan ini diharapkan dapat menambah penghasilan dan pendapatan bagi ibu - ibu petani. Letak Desa Kalampangan yang cukup strategis, merupakan jalur utama jalan provinsi yang menghubungkan Kalimantan Tengah dengan Kalimantan Selatan, sehingga sangat menguntungkan apabila hasil produk olahan berupa puding dan kue talam tersebut dipasarkan melalui warung, kedai, rumah makan sekitar jalur utama yang selalu ramai dilalui lalu lintas kendaraan sebagai transpotasi darat.

Kegiatan pengabdian ini meliputi penyuluhan interaktif tentang proses pembuatan produk olahan berbahan dasar jagung manis serta pelatihan berupa demonstrasi pembuatan puding dan kue talam.
Dilanjutkan pembinaan untuk keberlanjutan usaha, baik melalui monitoring maupun diskusi melalui telp. selulair. Tujuan dari kegiatan ini agar ibu - ibu mitra lebih kreatif dan inovatif dalam berkreasi mengolah produk makanan, baik untuk dijual maupun konsumsi sendiri guna menambah gizi keluarga. Apalagi untuk pengolahan produk makanan ini hanya perlu teknologi yang sederhana, dimana ibu - ibu petani pasti bisa mengerjakannya. Kontribusi mendasar pada khalayak sasaran adalah dengan pembuatan dua produk makanan yang terbuat dari jagung manis diharapkan menjadi rintisan wirausaha baru bagi ibu ibu petani guna menambah pendapatan income keluarga.

Adapun hal-hal yang perlu diperhatikan dan permasalahan yang ditemukan serta solusi yang ditawarkan 
selama kegiatan berlangsung adalah sebagai berikut:

a. Penggunaan takaran/banyaknya jagung manis yang telah disisir bijinya untuk bahan dasar pembuatan puding dan kue talam dapat ditambah/dikurangi sedikit dari takaran yang tertera pada bahan diatas (tergantung selera), apabila menyukai aroma jagung manis yang lebih dominan maka kebutuhan jagung manis perlu ditambah sedikit dari takarannya.

b. Selama proses pemasakan, sebaiknya adonan puding dan kue talam terus diaduk supaya tidak mengendap ke bawah dan mengakibatkan adonan hangus.

c. Saat pengolahan/memasak adonan puding dan kue talam, sebaiknya benar-benar masak, jangan langsung diangkat setelah mendididih, melainkan dibiarkan tetap mendidih untuk beberapa saat ( \pm 10-15 menit) sambil terus dianduk-aduk, agar hasil produk olahan tahan disimpan agak lama. Kalau kurang lama cara memasaknya, maka produk olahan akan cepat basi.

d. Untuk mempercantik warna puding dan kue talam biar tidak kuning pucat, bisa ditambahkan sedikit pewarna kue, hingga menghasilkan kuning cerah.

e. Produk olahan puding dan kue talam hanya bertahan setengah hari saja sehingga perlu inovasi teknologi guna peningkatan waktu saji lebih tahan lama (tidak mudah basi).

\subsection{Puding Jagung Manis}

a. Pada pembuatan puding, pemberian tepung maizena cukup 30 gr saja, karena apabila lebih akan mempengaruhi cita rasa jagung manis dan tekstur puding yang dihasilkan.

b. Pada saat memasak adonan puding jagung manis, harus diperhatikan saat olahan puding sudah hampir mendidih yaitu api harus dikecilkan dan terus diaduk agar olahan puding tidak naik keatas dan meluber keluar dari wadah.

c. Sebelum produk hasil olahan puding benar - benar dingin dan padat, jangan di keluarkan dari wadah cetakannya, karena akan hancur bentuknya, karena tekstur hasil produk olahan yang lembut dan mudah pecah apabila belum benar-benar dingin.

\subsection{Kue Talam Jagung Manis}

a. Saat memasak olahan kue talam, setelah mendidih dibiarkan untuk beberapa saat sampai benar-benar matang, sambil diaduk terusmenerus supaya adonan bagian bawah tidak hangus, tujuannya agar kue talam lebih tahan lama (tidak mudah basi) saat dipasarkan.

b. Untuk pembuatan kue talam, kebutuhan air tergantung dari selera, yaitu untuk hasil yang lembut/ kue tidak terlalu padat, maka kebutuhan air saat merebus irisan jagung manis yg telah diblender perlu ditambah sedikit dari volume yang tertera pada bahan tersebut diatas, sedangkan untuk hasil kue yang lebih padat maka kebutuhan air bisa dikurangi sedikit dari takarannya.

c. Perlu keseragaman bentuk untuk pembuatan takir sebagai wadah kue talam, untuk memperindah bentuk kue. Pada saat awal pembuatan takir, terdapat ketidakseragaman pada saat pembuatan takir dari daun pisang. Hal ini mempengaruhi kualitas hasil kue talam. 


\section{Kesimpulan Dan Saran}

\section{Kesimpulan}

1. Desa Kalampangan merupakan sentral tanaman jagung manis di wilayah Kota Palangka Raya. Hasil tongkol jagung manis selalu ada setiap saat bahkan kadangkala surplus produksinya, sehingga harga jual menjadi rendah. Oleh karena itu perlu alternatif pengolahan produk jagung manis menjadi diversifikasi produk olahan makanan agar harga jual jagung manis ditingkat petani tetap dapat dipertahankan.

2. Kontribusi yang diberikan kepada ibu ibu petani mitra adalah dengan pelatihan pembuatan dua produk makanan yang terbuat dari jagung manis (puding dan kue talam jagung manis), diharapkan menjadi rintisan wirausaha baru skala home industri sehingga dapat menambah pendapatan income keluarga sekaligus untuk konsumsi sendiri guna memenuhi gizi keluarga.

\section{Saran}

1. Untuk menghasilkan produk olahan puding dan kue talam jagung manis yang lebih baik kualitasnya, diperlukan kemasan produk hasil yang cantik dan menarik karena sangat mempengaruhi harga jual dan minat pembeli.

2. Saat mengeluarkan hasil olahan puding dan kue talam dari wadah/tempatnya, maka kondisi produk olahan harus benar - benar dingin karena teksturnya yang mudah hancur.
3. Produk olahan puding dan kue talam hanya bertahan setengah hari saja sehingga perlu inovasi teknologi guna peningkatan waktu saji lebih tahan lama (tidak mudah basi).

\section{Ucapan Terima Kasih}

Terima kasih disampaikan kepada Pascasarjana Universitas Palangka Raya yang telah mendanai keberlangsungan kegiatan Pengabdian ini.

\section{DAFTAR PUSTAKA}

Direktorat Jenderal Pemberdayaan Masyarakat dan Desa 2015. Profil Desa dan Kelurahan Kalampangan. Direktorat Jenderal Pemberdayaan Masyarakat dan Desa. Departemen Dalam Negeri 2009.http://kel-kalampangan. palangkaraya.go.id/wpcontent/uploads/2017/12/ Profil_Kel_Kalampangan $\underline{\text { 2015.pdf }}$

Firmansyah. A, 2015. Kalampangan Profil Desa Sukses di Pertanian Gambut Kalimantan Tengah. Tabloid Sinar Tani, $30 \quad$ Juli 2008. http://www.litbang.pertanian.go.id/ artikel/one/216/pdf/Kalampangan

https://cookpad.com > cari > talam jagung $\underline{\text { manis santan. Diakses pada tanggal }}$ 12 Juli 2019. 


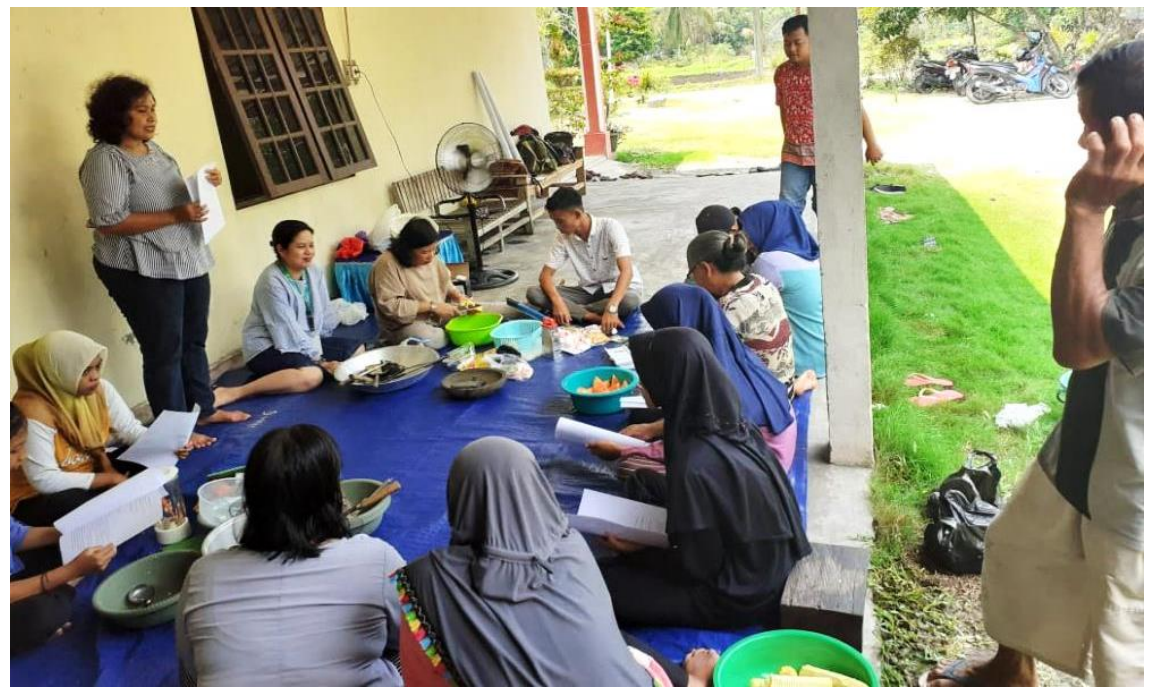

Gambar 2. Pengarahan Pelaksanaan Kegiatan dan Penyuluhan Pembuatan Produk Olahan Puding dan Kue Talam Jagung Manis

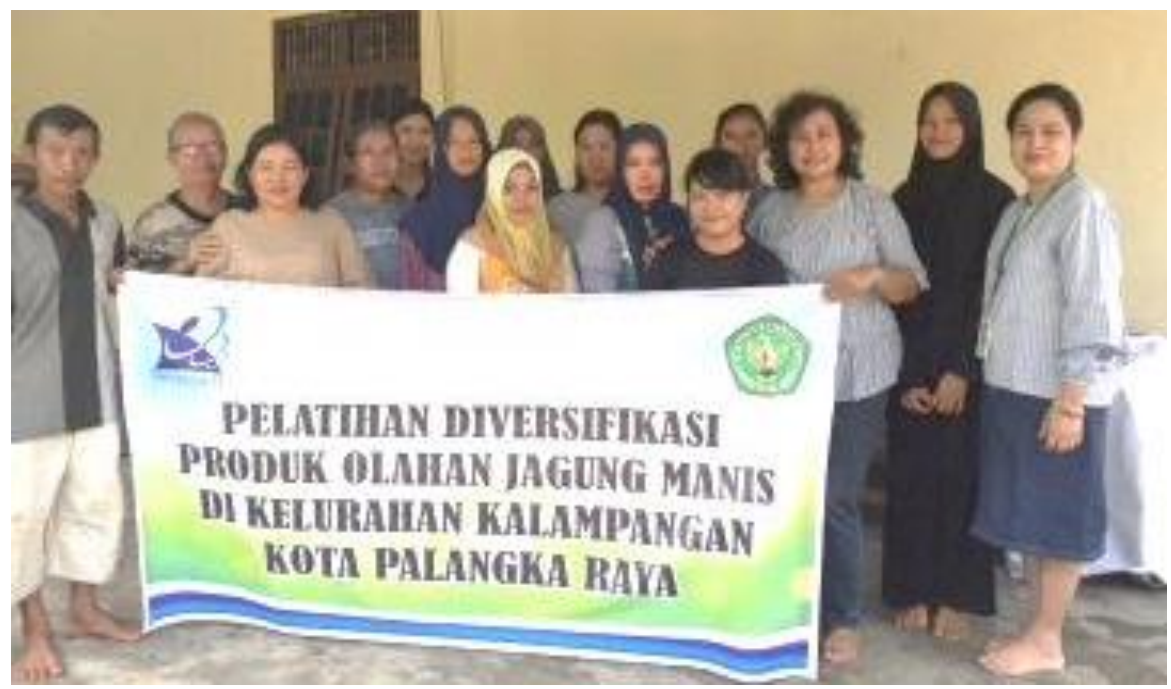

Gambar 3. Dokumentasi Selesai Kegiatan 